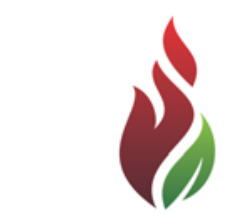

SUSTENERE

Publishing Corporation

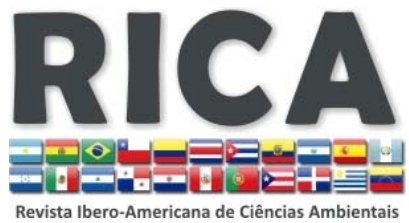

Journals Homepage:

www.sustenere.co/journals

\section{COASTAL DUNES CHANGES FROM 1966 TO 2001 IN THE DE LA PLATA RIVER, URUGUAY}

\section{ABSTRACT}

Hereby we present a historical reconstruction of the coastal landscape for an area of the dune system of Rio de la Plata in Uruguay. In order to achieve our purpose, we performed an analysis of photographs taken of the area in the years 1966, 1976, 1982, 1987, 1994 and 2001, which were loaded to a geographic data system. For a long period of time we detected an increment and advancement of the vegetation coverage towards the coast. Based on a logistic regression, we inferred a transmission pattern predicting that the system would achieve a maximum of $85 \%$ coverage via a model of cyrtoid phenomenon. These results make sense once we consider management plans for the restoration of degraded areas, which have been afforested in the past century with the purpose of disrupting the sand dune dynamics and facilitating urban development. Currently, those areas are densely populated with increasing reports of housing and infrastructure destruction due to beach loss and the invasion of exotic species. Our approach incorporates the historical vision of the landscape as a tool for the restoration of degraded ecosystems, and at the same time proposes certain strategies for the management and control of Acacia longifolia, which constitutes the main exotic species that has invaded and modified the dune system of coastal Rio de la Plata.

KEYWORDS: Acacia longifolia; Coastal Sand Dunes; Invasive Plant Species; Landscape Change; Uruguay.

\section{MUDANÇAS NAS DUNAS COSTEIRAS, DE 1966 A 2001 NO RIO DE LA PLATA, URUGUAI}

\section{RESUMO}

Nisto nós apresentamos uma reconstrução histórica da paisagem costeira para uma área do sistema de dunas do Rio de La Plata, no Uruguai. Para alcançar nosso objetivo, foi realizada uma análise de fotografias tiradas da área nos anos 1966, 1976, 1982, 1987, 1994 e 2001, os quais foram carregados de um sistema de informação geográfica. Por um longo período de tempo que detectou um incremento e avanço da cobertura de vegetação em direção à costa. Com base em uma regressão logística, nós inferir um padrão de transmissão prevendo que o sistema iria atingir um máximo de cobertura de $85 \%$ através de um modelo de fenômeno cyrtoid. Estes resultados fazem sentido, uma vez que consideram planos de gestão para a recuperação de áreas degradadas, que foram florestadas no século passado, com o fim de prejudicar a dinâmica de dunas de areia e facilitar o desenvolvimento urbano. Atualmente, essas áreas são densamente povoadas com o aumento relatos de habitação e infraestrutura de destruição devido à perda de praia e a invasão de espécies exóticas. Nossa abordagem incorpora a visão histórica da paisagem como uma ferramenta para a restauração de ecossistemas degradados, e ao mesmo tempo propõe algumas estratégias para o gerenciamento e controle de Acacia longifolia, que constitui as principais espécies exóticas que invadiu e modificaram o sistema de dunas costeira do Rio de La Plata.

PALAVRAS-CHAVE: Acacia Iongifolia; Dunas Costeiras; Plantas Invasoras Mudança de Paisagem; Uruguai
Revista Ibero-Americana de

Ciências Ambientais, Aquidabã, v.5, n.1, Dez 2013, Jan, Fev, Mar, Abr, Mai 2014.

ISSN 2179-6858

SECTION: Articles

TOPIC: Ecologia e Biodiversidade

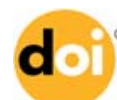

DOI: 10.6008/SPC2179-6858.2014.001.0003

\author{
Elena Castiñeira Latorre \\ Centro Universitario de Rivera, Uruguai \\ elencasti@gmail.com
}

Andrés Canavero

Centro Universitario de Rivera, Uruguai acanavero@gmail.com

Received: 25/01/2014

Approved: $15 / 05 / 2014$

Reviewed anonymously in the process of blind peer.

\section{Referencing this:}

LATORRE, E. C.; CANAVERO, A.. Coastal Dunes changes from 1966 to 2001 in the de La Plata River, Uruguay. Revista Ibero-Americana de Ciências Ambientais,

Aquidabã, v.5, n.1, p.27-37, 2014. DOI: http://dx.doi.org/10.6008/SPC21796858.2014.001.0003 


\section{INTRODUCTION}

The historical reconstruction of ecological modification processes can be a tool for biological conservation (JORDAN III et al., 2003; FOSTER, 2006; RHEMTULLA \& MLADENOFF, 2007; SÖNMEZ et al., 2009; GAUTREAU, 2010). In the present we possess a wide variety of resources at various scales to perform a historical reconstruction of landscapes and to generate handling and restoration schemes for degraded ecosystems (KUTIEL et al., 2004; ANDERSON et al., 2006; ARCENAZARIO, 2007; BANNER \& LEPAGE, 2008; SÖNMEZ et al., 2009; GAUTREAU, 2010; JONES \& VAUGHAN, 2010; HORNING et al., 2012; PAINE \& KISER, 2012). In the beginning of the twentieth century global programs were promoted to boost the afforestation with Acacia longifolia (Andrews) Will as a form of species capable of stabilizing dune systems, and allowing for increased development of urbanization and agricultural areas (CARRUTHERS et al., 2011; KULL et al., 2011). The concern for the negative impact of $A$. longifolia due to its invasive and modifying behavior is rather recent (KUTIEL et al., 2004; MARCHANTE et al., 2008, 2009; MARCHANTE et al., 2010, 2011a, b; MARCHANTE et al., 2011c). Several studies that analyze data from ecological and geographical perspectives also include a historical record to further understand the incidence of human occupation on Uruguayan ecosystems (BRACCO et al., 2005; CASTIÑEIRA, 2009; GAUTREAU, 2010; INDA et al., 2011; CASTIÑEIRA et al., 2013).

In Uruguay, several authors pointed out the growing alteration that coastal ecosystems have suffered as a consequence of the afforestation process with exotic species. In this sense, the coastal areas have turned out to be the most affected in the quality of their ecosystemic goods and services (PANARIO \& PIÑEIRO, 1997; DELFINO \& MASCIADRI, 2005; FAGÚNDEZ \& LEZAMA, 2005; MASCIADRI et al., 2006; MASCIADRI et al., 2010; MASCIADRI et al., 2013). In the coastal zone of "EI Pinar" beach resort (Canelones, Uruguay), there are historical precedents that describe the area of study with an extent of approximately 1000 meters from the main dune and perpendicular to the shoreline, with mobile dunes and scarce vegetal coating (LEGRAND, 1959). Since the 1920s, the afforestation of the area with exotic species began with $A$. longifolia, Eucalyptus spp., and Pinus spp. for the stabilization of the dunes and subsequent urbanization of the area (LEGRAND, 1959; CHEBATAROFF, 1973; ALONSO PAZ \& BASSAGODA, 1999; GUTIÉRREZ \& PANARIO, 2005; ALONSO PAZ et al., 2009; CASTIÑEIRA et al., 2013). Such activities transformed the physico-chemical variables of the site and determined new conditions that allowed for the establishment of vegetation communities (ARBOGAST et al., 2002; HESP, 2002; CARRUTHERS et al., 2011; CASTIÑEIRA et al., 2013).

In the highly vulnerable scenario of these environments, given by an increasing human pressure and climate change (IPCC, 2007), our work can be a contribution for the preservation and restoration plans, which are currently being carried out in the area. For that reason, through a time analysis of the vegetation coating advance between 1966 and 2001 by means of photographical proof loaded in a geographical data system, we describe and identify the degree of change the 
system has suffered during that period of time. We report an advancement pattern of the vegetation through time and a mechanism of contagion (PETERSON, 2002). Lastly, we discuss the effect of the observed process and how it should be considered in the management plans for the preservation of the coastal ecosystems.

\section{MATERIALS AND METHODS}

\section{Study Area}

Our work was performed in an area of 125.560 square meters on the shore of Rio de la Plata at "El Pinar" beach, in the province of Canelones, Uruguay ( $\left.34^{\circ} 48^{\prime} \mathrm{S}, 55^{\circ} 54^{\prime} \mathrm{W}\right)$ (Fig.1). The site is a touristic attraction with a total of 21,091 permanent inhabitants (INE, 2011). It comprises a coastal system of transgressive dunes originated by sea level variations during the Holocene (PANARIO \& PIÑEIRO, 1997; CAVALLOTTO et al., 2004; CAVALLOTTO et al., 2005). In the study area, the climate is temperate warm with a monthly average of $22.7^{\circ} \mathrm{C}$ maximum and $10.7^{\circ} \mathrm{C}$ minimum. The precipitation accumulated throughout the year reaches $1100 \mathrm{~mm}$ (BIDEGAIN \& CAFFERA, 1997). The vegetation is associated with psammosere environments in fixed dunes and foredunes, and also hydrophilic environments in interdune depressions. In the fixed dunes we find pastures dominated by Androtrichum trigynum (Spreng.) $\mathrm{H}$. Pfeiff, Achyrocline satureioides (Lam.) DC, Paspalum notatum Flüggé var. notatum, Schysachyrium $s p$ with brushwoods of $A$. longifolia and thickets of Pinus sp. In the fore dunes, we can observe a stratum of continuous vegetation predominantly consisting of Panicum racemosum (P. Beauv.) Spreng. and Spartina ciliata Brongn. while in the interdune depressions predominates Eryngium pandanifolium Cham. \& Schltdl., Schoenoplectus californicus (C.A. Mey.) Soják var. californicus, Polygonum acuminatum Kunth, Paspalum pumilum Nees, Typha domingensis Pers. and Typha latifolia L. (CASTIÑEIRA et al., 2013).

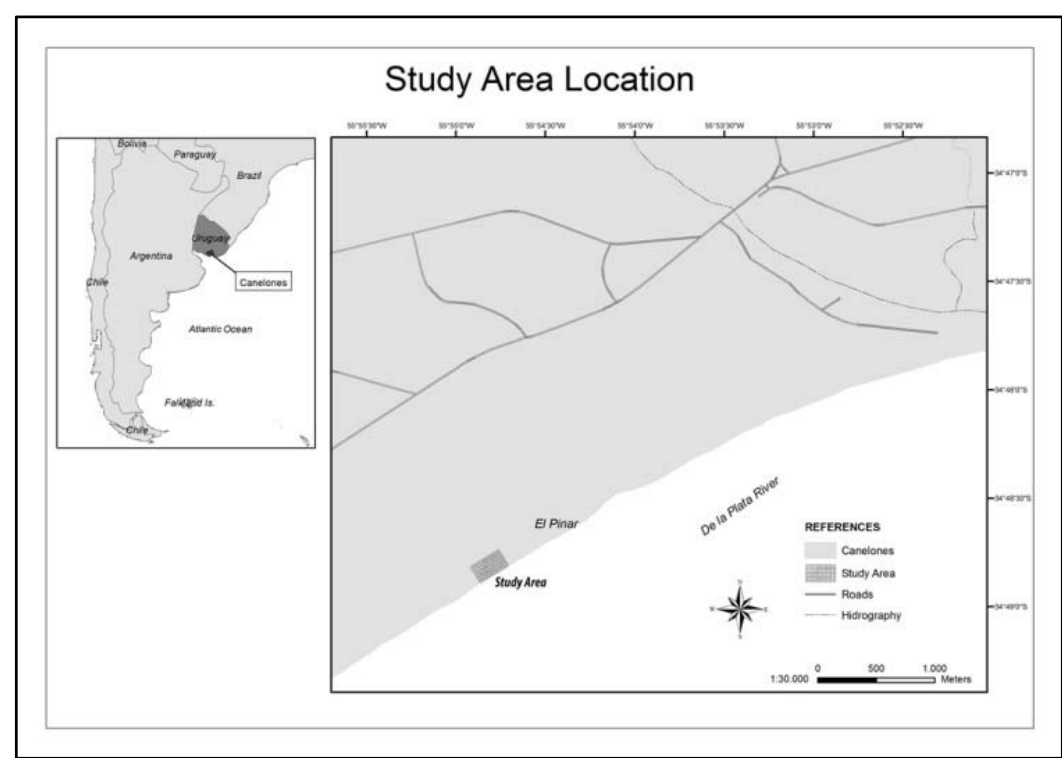

Figure 1: Map of Uruguay showing the location of the study area at "El Pinar" Canelones. 


\section{Image analysis}

A revision of cartography and aerial photographs obtained from the "Servicio de Sensores Remotos Aeroespaciales" of the Uruguayan Air force and the Geographic Military Service corresponding to the years 1966, 1976, 1982, 1987, 1994 and 2001 was carried out. The cartographic sheet of "El Pinar J-29" (scale 1: 50000) of the Geographic Military System (Gauss projection, contact meridian 62G, Datum Yacaré) was geo-referenced with the use of QGIS, a cross-platform free and open source desktop geographic information systems (GIS) application that provides data viewing, editing, and analysis capabilities. The aerial photographs were entered in the system with the use of a scanner and generating digital files with tif format. The georeferencing was performed manually using the QGIS program. For the process of geo-referencing, the work began with a cartographic sheet prepared from the aerial photograph of 1987; next, by locating discrete points, we proceeded to referencing the remaining series of images. In this way, we worked with a database in raster format for the representation of the spatial information, focusing on the distribution of the vegetation. An orthorectification of the aerial photographs was performed in order to diminish the perspective effects. In order to carry out the analysis of the temporal variation, a gridded matrix of $34 \times 50$ cells of $8.6 \times 8.6 \mathrm{~m}$, was generated. This matrix covers from the fixed dune (row 1) to the fore dune (row34) $292 \mathrm{~m}$ and $430 \mathrm{~m}$ in parallel to the shore line (Fig. 2).
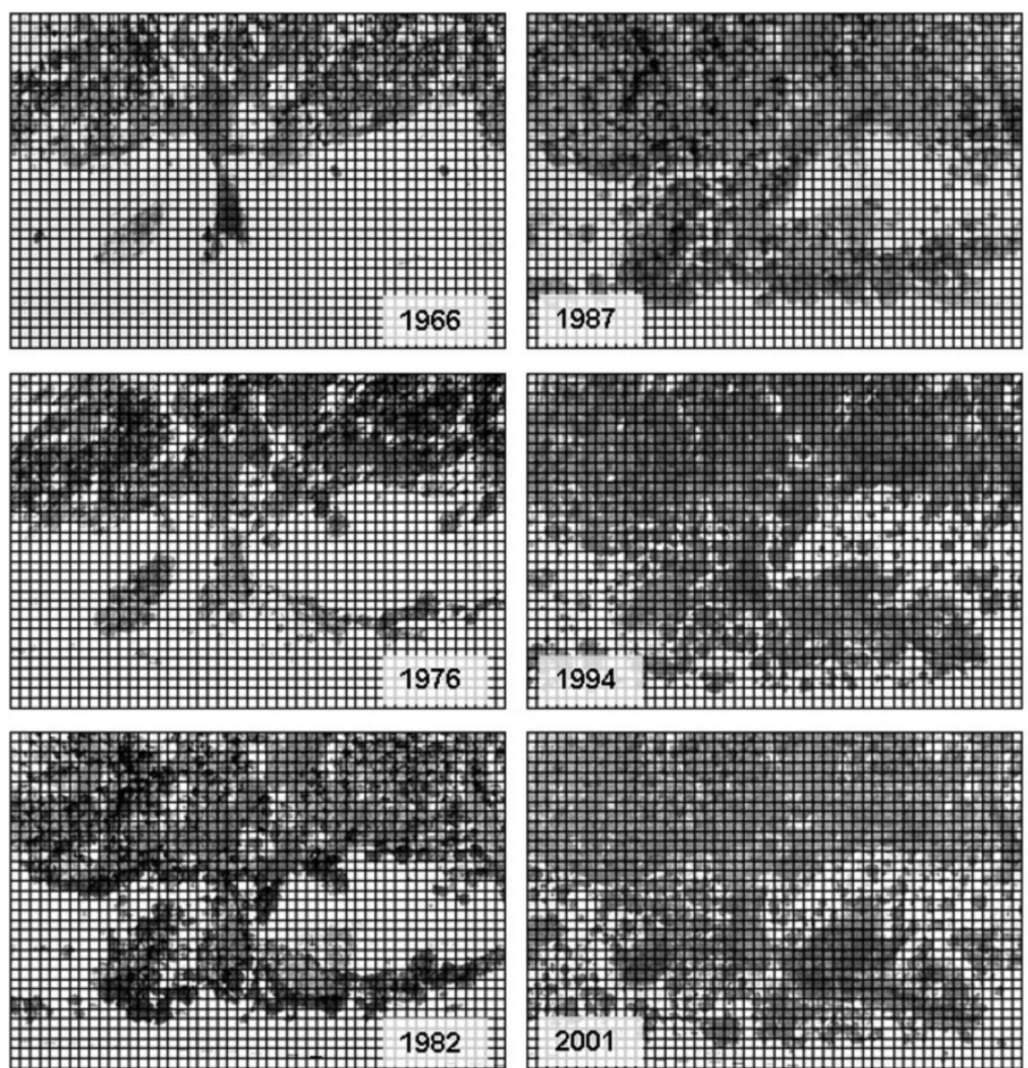

Figure 2: Aerial photographs of the years 1966, 1976, 1982, 1987, 1994 and 2001obtanined from the "Servicio de Sensores Remotos Aeroespaciales de la Fuerza Aérea Uruguaya" and "Servicio Geográfico Militar". Each photograph represents a graded matrix of $34 \times 50$ cells of 8,6 x 8,6 meters, which extends from a fixed dune (top of each photograph) to a foredune (bottom of each photograph) 292 meters and 430 meters parallel to the coastal shore. 
The minimal unit of spatial resolution (pixel) represents a numerical matrix in shades of grey. The shades of grey have been standardized in the various photographs, and considered as: "presence of vegetation" (1) -the values larger than the average of the maximum and minimum; and "absence of vegetation" $(0)$ - those values lower than the average of maximum and minimum.

\section{Statistical Analysis}

A logistic regression was performed with the purpose of testing whether there is an association between the number of occupied neighboring cells (independent variable) and the probability of occupation of the central cell (dependent variable) (QUINN \& KEOUGH, 2002). We generated a vector of presence/absence with the data from each of the six grids together. To estimate the maximum value of coverage that the system will achieve, the following cyrtoid phenomenological model was adjusted (BERRYMAN, 1999):

$$
y=\frac{a *(x+b)}{(x+c)+d}
$$

Where $\mathbf{y}$ is the percentage of coverage (number of occupied cells / number of total cells), $\mathbf{x}=$ year of observation, $\mathbf{a}=$ disagreement of the function or estimated value the $1 \%$ of vegetation coating will achieve, b, c y $\mathbf{d}=$ model adjustment parameters (ZAR, 1999).

\section{RESULTS AND DISCUSSION}

The stabilization of the dune system may be associated with the pattern of contagion we discovered in the vegetation coating based on the logistic regression's results implying that as the number of neighboring occupied cells increases, the probability of cell occupation significantly increases (Table 1, Fig. 3). This may help smooth the harshness of the coastal environment, allowing for the establishment and persistence of propagules from nearby sources (PICKETT \& MCDONNELL, 1989; BERTNESS \& CALLAWAY, 1994; BERTNESS \& HACKER, 1994). Although it is true that a process of structural change and conditions of the environment occurs under the contagion model, the physical stress factors still impose limitations on vegetation coverage. In fact, although the percentage of total coverage shows a raise in the time $(p<0.01)$, it achieves a maximum value appraised through a phenomenological cyrtoid model of $85.1 \%$ (Fig. 4).

Table 1: Logistic regression between probability of cell occupation and number of neighbor cells occupied. P $=$ probability of the coefficients in the logistic regression.

\begin{tabular}{ccccc}
\hline Parameter & Estimate & Standard Error & Wald statistic & $\mathbf{P}$ \\
\hline$\beta 0$ & -3.573 & 0.077 & 2180.56 & $<0.001$ \\
$\beta 1$ & 0.866 & 0.016 & 2912.78 & $<0.001$ \\
\hline
\end{tabular}




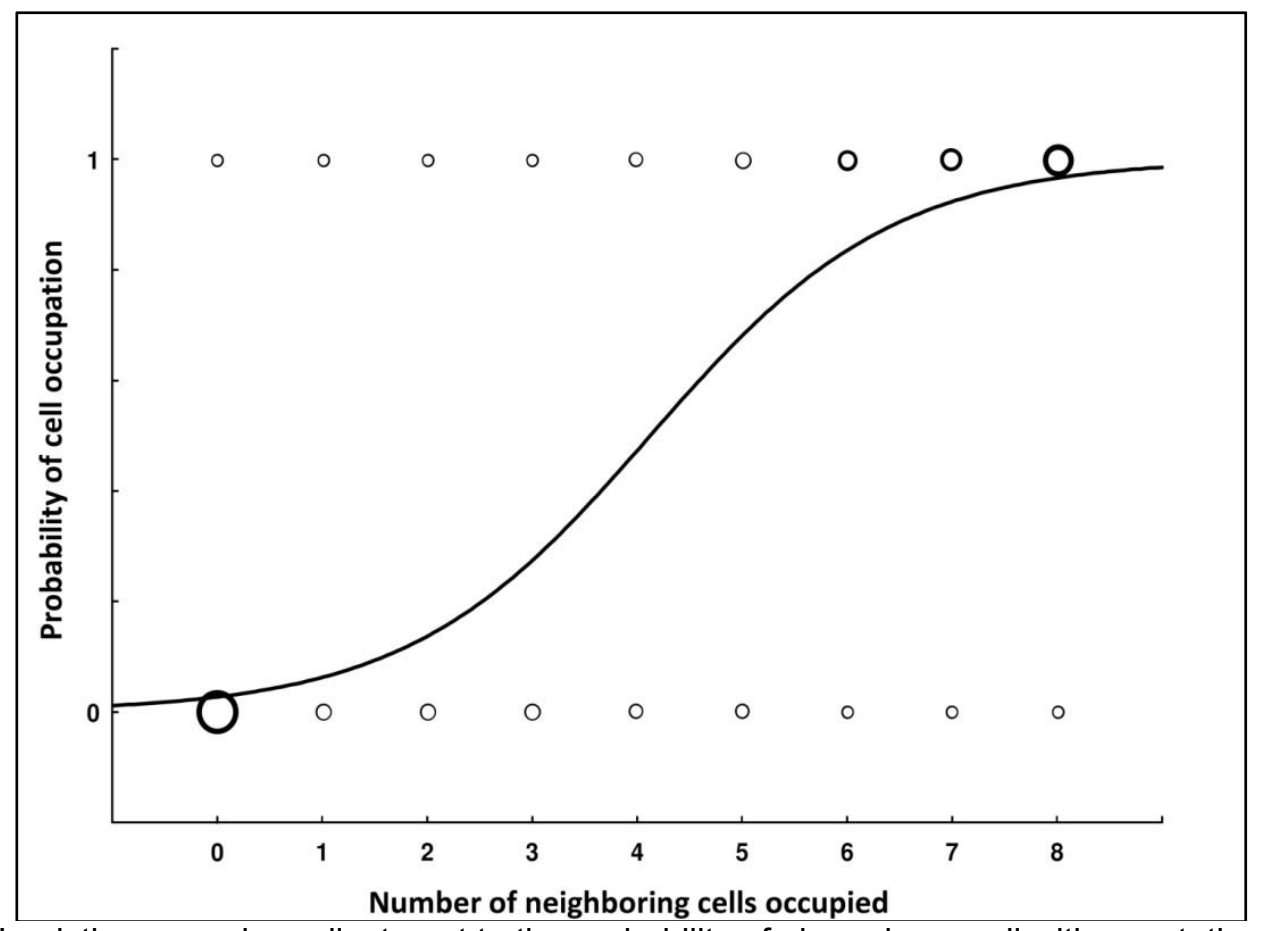

Figure 3: Logistic regression adjustment to the probability of observing a cell with vegetation given the number of occupied cells around it. $y=\exp \left(-3.57+0.87^{*} x\right) /\left(1+\exp \left(-3.57+0.87^{*} x\right)\right)$, where $y=$ probability of cell occupation, $x=$ number of neighboring cells occupied.

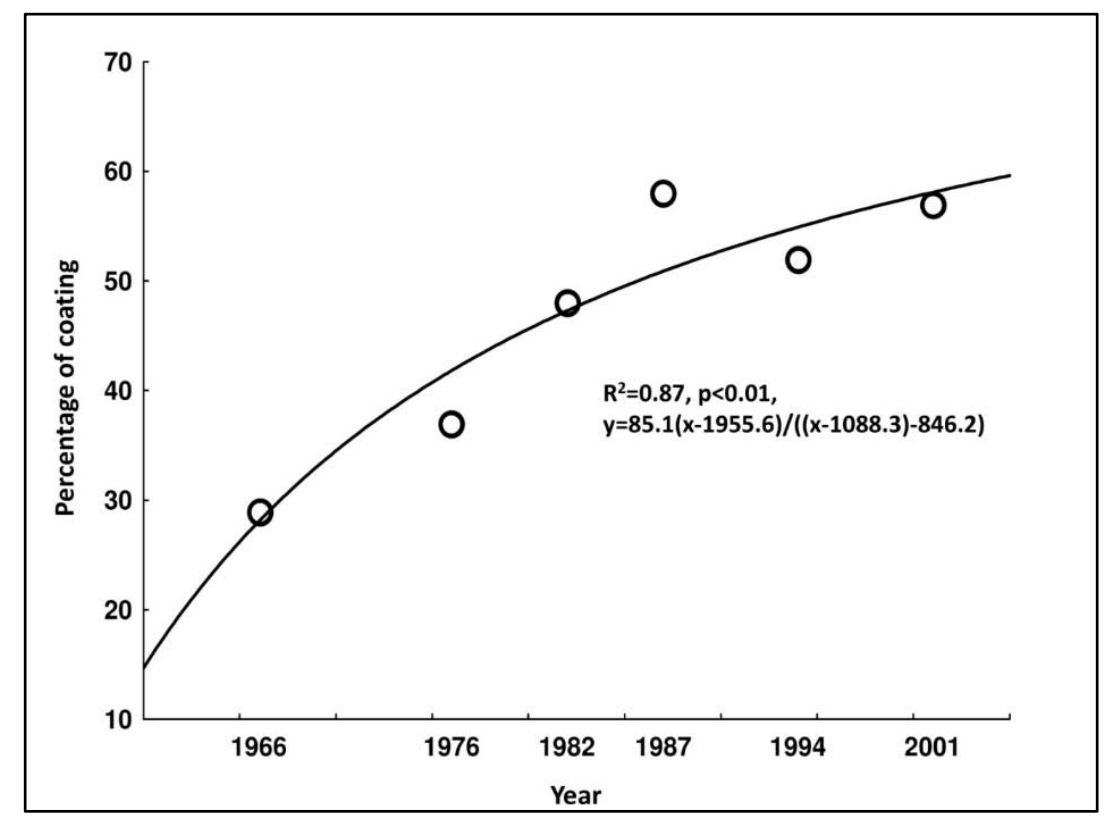

Figure 4: Non-linear regression between coating percentage versus the year adjusted to the cyrtoid model: porcentaje of coating $=a^{*}($ year $+b) /((y e a r+c)+d) ; a=$ Asymptote of the function; $b, c$ y $d=$ adjustment parameters.

During eight decades, the Uruguayan coastal areas have suffered an increasing modification as a consequence of poorly-planned historical urban development. Dune areas have been afforestated with exotic species such as $A$. longifolia and Pinus spp. to stabilize the dunes by preventing the natural transport dynamics of the sand and facilitating urban development (LEGRAND, 1959; CHEBATAROFF, 1973; GUTIÉRREZ \& PANARIO, 2005; ALONSO PAZ \& BASSAGODA, 2006). The study area corresponds to a relict system of dune strings derived from a larger ecosystem once formed by active dunes, that extended 1000 meters inland from the farthest 
dune string seen nowadays with scarce vegetation coating (LEGRAND, 1959). After the area was afforestated with $A$. longifolia and Pinus spp., two main alterations took place: one in the dynamics transportation of the sand and the other in the enrichment of the soil. The species planted are able to develop in nutrient-poor soils due to the symbiotic association with nitrogen-fixating bacteria in A. longifolia and the formation of mycorrhiza in Pinus spp. (HORTON et al., 1998; MARCHANTE et al., 2009; RODRÍGUEZ-ECHEVERRÍA et al., 2009; KULL et al., 2011). The sand accumulates through the effect of the introduced vegetation producing fixed dunes and interdune depressions with sand deficit whereby the water table surfaces (ARBOGAST et al., 2002; HESP, 2002; HERRMANN et al., 2008). A. longifolia spawns changes in the structure and microbiological processes while it increases soil acidification and the concentration of nutrients such as carbon and nitrogen (MARCHANTE et al., 2009; MARCHANTE et al., 2010, 2011a, b; MARCHANTE et al., 2011c). In this study we report an advancement pattern in the indigenous and exotic vegetation on the coastal dunes, as well as in other dune systems where similar processes have taken place (KUTIEL et al., 2004; SÝKORA et al., 2004; JUDD et al., 2008; MARCHANTE et al., 2009). Even though $A$. longifolia turns out to be a pioneer species in the fixation of dunes and the settlement of new vegetation associations, in other studies it has been reported as an invader that displaces the indigenous vegetation of coastal ecosystems (MARCHANTE et al., 2008, 2009; MARCHANTE et al., 2010, 2011a, b; MARCHANTE et al., 2011c). Bertness \& Hacker (1994) propose that in high physical stress subjugated environments the system is dominated by mainly positive interaction, as such condition eases in time or space, the system will turn to more competitive interactions. In this manner, in the first stage $A$. longifolia might behave as a facilitator species, while as the process moves forward it might act as an invader species (CASTIÑEIRA et al., 2013). This hypothesis can be tested by analyzing the behavior of vegetation successions experimentally generated in artificially degraded areas of the Rio de la Plata shore.

The formation of a neo-ecosystem, such as the one reported in this paper, may contribute to an increase in the degradation and retrogression of the coastal line. This situation is relevant to a densely populated area with an ongoing problem of housing and infrastructure destruction caused by beach loss (GUTIÉRREZ \& PANARIO, 2006). Uruguay is presently conducting restoration plans and research programs for the sustainability and handling of an integrated coastline (MENAFRA et al., 2009). From the viewpoint of biological conservation, these neoecosystems may be currently acting as biological corridors connecting the fauna and flora of coastal wetland areas such as "Bañados de Carrasco" and "Bañados del Arroyo Pando" near our study site in "EI Pinar". However, in the future these ecosystems harbouring indigenous and exotic species, are at risk of being dominated by the highly invasive $A$. longifolia, with serious detrimental effects in their diversity (MARCHANTE et al., 2010, 2011a, b; MARCHANTE et al., 2011c). 


\section{CONCLUSION}

In this study we emphasize the need to control for the natural dynamics of the sand dunes in order to achieve a harmonious urban development compatible with the long-term preservation of the coastal line. For that, we propose a handling of $A$. longifolia which includes basic investigation of seed banks, along with spread and control mechanisms of its potential invasion. We recommend the partial removal of $A$. longifolia with the purpose of maintaining the positive interaction within the vegetation community that allows for the sustainment of the biodiversity and restoration of degraded sand dunes. We believe that the incorporation of the historical reconstruction of degraded sites constitutes a powerful tool for contributing to the better understanding the function and restoration of threatened ecosystems (CASTIÑEIRA et al., 2013).

\section{REFERENCES}

ALONSO PAZ, E.; BASSAGODA, M. J.. Los bosques y los matorrales psamófilos en el litoral platense y atlántico del Uruguay. Comunicaciones botánicas del Museo de História Natural de Montevideo, v.6, n.113, p.8, 1999.

ALONSO PAZ, E.; BASSAGODA, M. J.. Flora y vegetación de la costa platense y atlántica uruguaya. In MENAFRA, R.; RODRÍGUEZ-GALLEGO, L.; SCARABINO, F.; CONDE, D.. Bases para la conservación y el manejo de la costa uruguaya. Montevideo: Vida Silvestre Uruguay, p 71-88, 2006.

ALONSO PAZ, E.; BEYHAUT, R.; DELFINO, L.; HARETCHE, F.; FAGÚNDEZ, C.; MARCHESI, E. 2009. Especies de plantas vasculares prioritarias para la conservación. Dirección Nacional de Medio Ambiente (DINAMA), Montevideo.

ANDERSON, N. J.; BUGMANN, H.; DEARING, J. A.; GAILLARD, M. J.. Linking palaeoenvironmental data and models to understand the past and to predict the future. Trends in Ecology and Evolution, v.21, n.12, p.696-704, 2006.

ARBOGAST, A. F.; HANSEN, E. C.; VAN OORT, M. D.. Reconstructing the geomorphic evolution of large coastal dunes along the southeastern shore of Lake Michigan. Geomorphology, v.46, p.241-255, 2002.

ARCE-NAZARIO, J. A.. Human landscapes have complex trajectories: reconstructing Peruvian Amazon landscape history from 1948 to 2005. Landscape Ecology, v.22, p.89-101, 2007.

BANNER, A.; LEPAGE, P.. Long-term recovery of vegetation communities after harvesting in the coastal temperate rainforests of northern British Columbia. Can. J. For. Res., v.38, p.3098-3111, 2008.

BERRYMAN, A. A.. Principles of Population Dynamics and Their Application Cheltenham, U.K.: Stanley Thornes, 1999.

BERTNESS, M. D.; CALLAWAY, R.. Positive interactions in communities. Trends in ecology and evolution, v.9, p.191-193, 1994.

BERTNESS, M. D.; HACKER, S. D.. Physical stress and positive associations among marsh plants. American Naturalist, v.144, p.363-372, 1994.

BRACCO, R.; DEL PUERTO, L.; INDA, H.; CASTIÑEIRA, C.. Mid late Holocene cultural and environmental dynamics in eastern Uruguay. Quaternary International, v.132, p.37-45, 2005.

CARRUTHERS, J.; ROBIN, L.; HATTINGH, J.; KULL, C.; RANGAN, H.; VAN WILGEN, B.. A native at home and abroad: the history, politics, ethics and aesthetics of acacias. Diversity and Distributions, v. 17, p.810821, 2011. 
CASTIÑEIRA, C.. Aspectos de la colonización humana prehistórica del noroeste del Uruguay. Arqueología, v.15, p.241-245, 2009.

CASTIÑEIRA, E.; FAGÚNDEZ, C.; DA COSTA, E.; CANAVERO, A.. Composition and vegetation structure in a system of coastal dunes of the "de la Plata" River, Uruguay: a comparison with Legrand's descriptions (1959). Brazilian Journal of Botany, v.36, n.1, p.9-23, 2013.

CAVALLOTTO, J. L.; VIOLANTE, R. A.; COLOMBO, F.. Evolución y cambios ambientales de la llanura costera de la cabecera del Río de la Plata. Revista de la Asociación Geológica Argentina, v.60, n.2, p.353-367, 2005.

CAVALLOTTO, J. L.; VIOLANTE, R. A.; PARKER, G.. Sea-level fluctuations during the last 8600 years in the de la Plata River (Argentina). Quaternary International, v.114, p.155-165, 2004.

CHEBATAROFF, J.. Ambientes salinos; su vegetación. Problemas de utilización. Montevideo: Facultad de Humanidades y Ciencias, Departamento de Geografía, 1973.

DELFINO, L.; MASCIADRI, S.. Relevamiento florístico en el Cabo Polonio, Rocha, Uruguay. Iheringia, Série Botanica, v.60, p.119-128, 2005.

FAGÚNDEZ, C.; LEZAMA, F.. Distribución espacial de la vegetación costera del litoral platense y atlantico uruguayo. Informe Freplata, p.36, 2005.

FOSTER, D. R.. The importance of land use history to conservation biology. In GROOM, M. J.; MEFFE, G. K.; CARROLL, C. R.. Principles of Conservation Biology: Sinauer Associates, Inc., Massachusetts, p.204207, 2006.

GAUTREAU, P.. Rethinking the dynamics of woody vegetation in Uruguayan campos, 1800-2000. Journal of Historical Geography, v.36, p.194-204, 2010.

GUTIÉRREZ, O.; PANARIO, D.. Dinámica geomorfológica de la desembocadura del Arroyo Pando, Uruguay. Geografía histórica y SIG, análisis de tendencias naturales y efectos antrópicos sobre sistemas dinámicos. Xeogáfica, n.5, p.107-126, 2005.

GUTIÉRREZ, O.; PANARIO, D.. Evolución de la desembocadura del Arroyo Pando (Canelones, Uruguay): ¿tendencias naturales o efectos antrópicos? In MENAFRA, R.; RODRÍGUEZ-GALLEGO, L.; SCARABINO, F.; CONDE, D.. Bases para la conservación y el manejo de la costa uruguaya. Montevideo: Vida Silvestre, p.391-400, 2006.

HERRMANN, H. J.; DURA, O.; PARTELI, E. J. R.; SCHATZ, V.. Vegetation and Induration as sand dunes stabilizators. Journal of Coastal Research, v.24, n.6, p.1357-1368, 2008.

HESP, P.. Foredunes and blowouts: initiation, geomorphology and dynamics. Geomorphology, v.48, p.245268, 2002.

HORNING, N.; ROBINSON, J. A.; STERLING, E. J.; TURNER, W.; SPECTOR, S.. Remote Sensing for ecology and conservation. A handbook of techniques. Oxford: University Press, 2012.

HORTON, T. R.; CÁZARES, E.; BRUNS, T. D.. Ectomycorrhizal, vesicular-arbuscular and dark septate fungal colonization of bishop pine (Pinus muricata) seedlings in the first five months of growth after wildlife. Mycorrhiza, v.8, p.11-18, 1998.

INDA, H.; DEL PUERTO, L.; BRACCO, R.; CASTIÑEIRA, C.; CAPDEPONT, I.; GASCUE, A.; BAEZA, J.. Relación hombre-ambiente para la costa estuarina y oceánica de Uruguay durante el Holoceno. Reflexiones y perspectivas. In GARCÍA-RODRÍGUEZ, F. EI Holoceno en la zona costera del Uruguay. Montevideo: Bibliotecaplural, UDELAR, SCIC, p.229-260, 2011.

IPCC. Cambio climático 2007: Informe de síntesis. Ginebra, Suiza: Grupo Intergubernamental de Expertos sobre el Cambio Climático, 2007. 
JORDAN III, W. R.; GILPIN, M. E.; ABER, J. D.. Restoration ecology: A synthetic approach to ecological research. Cambridge University Press ed. Cambridge, 2003.

JUDD, F. W.; SUMMY, K. R.; LONARD, R. I.; MAZARIEGOS, R.. Dune and vegetation stability at South Padre Island, Texas, United States of America. Journal of Coastal Research, v.24, n.4, p.992-998, 2008.

KULL, C. A.; SHACKLETON, C. E.; CUNNINGHAM, P. J.; DUCATILLON, C.; DUFOUR-DROR, J. M.; ESLER, K. J.; FRIDAY, J. B.; GOUVEIA, A. C.; GRIFFIN, A. R.; MARCHANTE, E.; MIDGLEY, S. J.; PAUCHARD, A.; RANGAN, H.; RICHARDSON, D. M.; RINAUDO, T.; TASSIN, J.; URGENSON, L. S.; VON MALTITZ, G. P.; ZENNI, R. D.; ZYLSTRA, M. J.. Adoption, use and perception of Australian acacias around the world. Diversity and Distributions, v.17, p.822-836, 2011.

KUTIEL, P.; COHENA, O.; SHOSHANY, M.; SHUBB, M.. Vegetation establishment on the southern Israeli coastal sand dunes between the years 1965 and 1999. Landscape and Urban Planning, v.67, p.141-156, 2004.

LEGRAND, D.. Comunidades psamófilas de la región de Carrasco (Uruguay). Anales del Museo de Historia Natural, v.6, n.7, p.73, 1959.

MARCHANTE, E.; KJØLLER, A.; STRUWE, S.; FREITAS, H.. Short- and long-term impacts of Acacia longifolia invasion on the belowground processes of a Mediterranean coastal dune ecosystem. Applied Soil Ecology, v.40, p.210-217, 2008.

MARCHANTE, E.; KJØLLER, A.; STRUWE, S.; FREITAS, H.. Soil recovery after removal of the N2-fixing invasive Acacia longifolia: consequences for ecosystem restoration. Biological Invasions, v.11, p.813-823, 2009.

MARCHANTE, H.; FREITAS, H.; HOFFMANN, J. H.. Seed ecology of an invasive alien species, Acacia longifolia (Fabaceae), in portuguese dune ecosystems. American Journal of Botany, v.97, p.1780-1790, 2010.

MARCHANTE, H.; FREITAS, H.; HOFFMANN, J. H.. Assessing the suitability and safety of a well-known bud-galling wasp, Trichilogaster acaciaelongifoliae, for biological control of Acacia longifolia in Portugal Biological Control, v.56, p.193-201, 2011.

MARCHANTE, H.; FREITAS, H.; HOFFMANN, J. H.. Post-clearing recovery of coastal dunes invaded by Acacia longifolia: is duration of invasion relevant for management success? . Journal of Applied Ecology, v.48, p.1295-1304, 2011.

MARCHANTE, H.; FREITAS, H.; HOFFMANN, J. H.. The potential role of seed banks in the recovery of dune ecosystems after removal of invasive plant species. Applied Vegetation Science, v.14, p.107-119, 2011.

MASCIADRI, S.; BRUGNOLI, E.; MUNIZ, P.. InBUy database of Invasive and Alien Species (IAS) in Uruguay: a useful tool to confront this threat to biodiversity. Biota Neotropica, v.10, n.4, p.1-9, 2010.

MASCIADRI, S.; FIGUEREDO, E.; DELFINO, L.. Fisonomía y composición florística de Cabo Polonio (Rocha, Uruguay). In MENAFRA, R.; RODRÍGUEZ-GALLEGO, L.; SCARABINO, F.; CONDE, D.. Bases para la conservación y el manejo de la costa uruguaya. Montevideo: Vida Silvestre Uruguay, 2006.

MASCIADRI, S.; STUTZ, S.; GARCÍA-RODRÍGUEZ, F.. Modern pollen-vegetation relationship of plant communities in the Uruguayan Atlantic coast. Brazilian Journal of Botany, v.36, n.1, p.31-44, 2013.

MENAFRA, R.; CONDE, D.; ROCHE, I.; GORFINKIEL, D.; PIRIZ, C.; BALIERO, W.; BIASCO, E.; FOSSATI, M.; LORENZO, E.; CORTAZZO, R.. Challenges and opportunities for integrated coastal management in Uruguay. Environment and coastal management, v.23, p.403-432, 2009.

PAINE, D. P.; KISER, J. D.. Aerial photography and Image interpretation. New Jersey: John Wiley \& Sons, Inc. Hoboken, 2012.

PANARIO, D.; PIÑEIRO, G.. Vulnerability of oceanic dune systems under wind pattern change scenarios in Uruguay. Climate Research, v.9, p.67-72, 1997. 
PETERSON, G. D.. Contagious disturbance, ecological memory, and the emergence of landscape pattern. Ecosystems, v.5, p.329-338, 2002.

PICKETT, S. T. A.; MCDONNELL, M. J.. Changing perspectives in community dynamics: a theory of successional forces. Trends in Ecology and Evolution, v.4, p.241-245, 1989.

QUINN, G. P.; KEOUGH, M. J.. Experimental design and data analysis for biologists. Cambridge: Cambridge University Press, 2002.

RHEMTULLA, J. M.; MLADENOFF, D. J.. Why history matters in landscape ecology. Landscape Ecology, v.22, p.1-3, 2007.

RODRÍGUEZ-ECHEVERRÍA, S.; CRISÓSTOMO, J. A.; NABAIS, C.; FREITAS, H.. Belowground mutualists and the invasive ability of Acacia longifolia in coastal dunes of Portugal. Biol Invasions, v.11, p.651-661, 2009.

SÖNMEZ, N. K.; ONUR, I.; SARI, M.; MAKTAV, D.. Monitoring changes in land cover/use by CORINE methodology using aerial photographs and IKONOS satellite images: a case study for Kemer, Antalya, Turkey. International Journal of Remote Sensing, v.30, n.7, p.1771-1778, 2009.

SÝKORA, K. V.; BOGERT, J. C. J. M. V. D.; BERENDSE, F.. Changes in soil and vegetation during dune slack succession. Journal of Vegetation Science, v.15, n.2, p.209-218, 2004.

ZAR, J. H.. Biostatistical Analysis Prentice-Hall, Inc, 1999. 